\title{
Interpretation of Serum Visfatin Level in Relation to Hepatic Injury is Probably Gender Dependent in Nonalcoholic Fatty Liver Disease
}

\author{
Bahareh Amirkalali, ${ }^{1}$ Masoud Reza Sohrabi, ${ }^{1}$ Ali Gholami, ${ }^{2,3}$ Payam Hosseinzadeh, ${ }^{1}$ Farzad Shidfar, ${ }^{4,}$ \\ and Farhad Zamani ${ }^{1, * *}$ \\ ${ }^{1}$ Gastrointestinal and Liver Disease Research Center (GILDRC), Iran University of Medical Sciences, Tehran, Iran \\ ${ }^{2}$ Department of Public Health, School of Public Health, Neyshabur University of Medical Sciences, Neyshabur, Iran \\ ${ }^{3}$ Department of Epidemiology, School of Public Health, Iran University of Medical Sciences, Tehran, Iran \\ ${ }^{4}$ Department of Nutrition, School of Public Health, Iran University of Medical Sciences, Tehran, Iran \\ "Corresponding author: Farzad Shidfar, Shahid Hemmat Highway, Iran University of Medical Sciences. Tel: +98-2188622721, E-mail: f-shidfar@tums.ac.ir \\ "Corresponding author: Farhad Zamani, Postal Address: Karim khan Blv., Behafarin Street, Firoozgar Hospital, Gastrointestinal and Liver Disease Research Center, Tehran, Iran. \\ Tel: +98-2188940489, E-mail: zamani.farhad@gmail.com
}

Received 2016 November 06; Revised 2017 March 04; Accepted 2017 April 30.

\begin{abstract}
Background: Studies on the association between visfatin and nonalcoholic fatty liver disease (NAFLD) have contradictory results and the role of this adipokine in NAFLD pathogenesis has remained unclear. In vitro studies indicate that visfatin expression could be regulated by sex hormones. Testosterone down-regulates visfatin expression in pre-adipocytes and estrogen increases its expression in adipocytes.

Objectives: This study aimed at exploring whether the association between serum visfatin and markers of hepatic injury is the same for both genders in patients with NAFLD.

Methods: In this cross-sectional study, 62 consecutive patients (32 males and 30 females) with NAFLD were recruited. Fasting serum visfatin, caspase-cleaved cytokeratin 18 (cCK18), total soluble cytokeratin 18 (CK18), liver enzymes (AST and ALT), insulin, and lipidglucose profile was measured. Anthropometric measurements, fibroscan and assessment of dietary intake and physical activity level, were performed for each participant. Two independent sample t tests, chi-square test, univariate, and multiple linear regression (to adjust for confounding factors) were used to analyze the data.

Results: In males, serum visfatin had a significant positive association with serum Aspartate Aminotransferase $($ AST $)(B=0.47, \mathrm{P}=$ 0.009), alanine aminotransferase ( $\mathrm{ALT})(\mathrm{B}=0.40, \mathrm{P}=0.035)$, $\mathrm{CK1} 18(\mathrm{~B}=0.50, \mathrm{P}=0.008)$, and cCK18 $(\mathrm{B}=0.47, \mathrm{P}=0.012)$. In females, serum visfatin only had a weak association with $C$ K18 $(B=0.37, P=0.045)$. Instead, higher body mass index (BMI) was significantly associated with increased serum $\mathrm{CK1} 18(\mathrm{~B}=0.44, \mathrm{P}=0.02)$, cCK18 $(\mathrm{B}=0.42, \mathrm{P}=0.02)$, controlled attenuation parameter $(\mathrm{CAP})(\mathrm{B}=$ $0.39, P=0.049)$, and liver stiffness measurement $(\mathrm{LSM})(\mathrm{B}=0.40, \mathrm{P}=0.03)$ in females. Higher waist to hip ratio was also significantly related to serum AST $(B=0.37, P=0.04)$, ALT $(B=0.50, P=0.02)$, CK18 $(B=0.41, P=0.03)$, CCK18 $(B=0.37, P=0.04)$, and CAP $(B=0.39$, $\mathrm{P}=0.04)$ in this group. In this study, females were significantly older $(47.83 \pm 81.10$ vs $39.84 \pm 12.10, \mathrm{P}=0.008)$ and had higher $\mathrm{BMI}$ ( $32.31 \pm 4.56$ vs $29.42 \pm 4.89, \mathrm{P}=0.02$ ) compared to males, thus the associations were adjusted for age, BMI, and other confounders. Conclusions: Interpretation of serum visfatin level in relation to hepatic injury was probably gender-dependent in NAFLD. While its increased serum level could be an indicator for more hepatic injury in males, this was not the case in females. Body Mass Index and waist to hip ratio were stronger predictors for hepatic injury in females.
\end{abstract}

Keywords: Visfatin, Gender, Non-Alcoholic Fatty Liver

\section{Background}

Nonalcoholic fatty liver disease (NAFLD) is one of the most common liver diseases around the world $(1,2)$ and its prevalance has grown due to unhealthy life styles (3). The disease has a wide spectrum from simple steatosis to nonalcoholic steatohepatitis (NASH), which is hepatic steatosis accompanied by inflammation or liver cell injury with or without fibrosis (4). Furthermore, NASH could lead to fibrosis and cirrhosis (5) and ultimately to hepatocellular carcinoma (6).

Many studies have explored the association between adipose tissue derived cytokines and the progress of $\operatorname{NAFLD}(7,8)$. Visfatin is a novel adipocytokine, known for its cytokine function (9) and enzymatic role in the production of Nicotinamide Adenine Dinucleotide (NAD). Both of these functions could play an important role in the progression of NAFLD. Its cytokine function could effect the hepatic inflammatory state and its enzymatic role could regulate NAD-consuming enzymes on different metabolic pathways, including hepatic De Novo Lipogenesis (DNL) $(10,11)$.

Studies on the association between visfatin and

Copyright (c) 2017, Hepatitis Monthly. This is an open-access article distributed under the terms of the Creative Commons Attribution-NonCommercial 4.0 International License (http://creativecommons.org/licenses/by-nc/4.0/) which permits copy and redistribute the material just in noncommercial usages, provided the original work is properly cited. 
NAFLD have had contradictory results and the role of this adipokine in NAFLD pathogenesis has remained unclear (12-14). For instance, Aller et al. indicated that serum visfatin level was associated with portal inflammation in patients with NAFLD, yet had no relationship with steatosis or fibrosis (15). Dahl et al. reported that serum visfatin level in obese patients with NAFLD, was markedly decreased compared with healthy controls, with no difference between simple steatosis and NASH (16). Jarrar et al. (17) and Younossi et al. (18) showed significantly lower serum visfatin levels in patients with NASH compared to simple steatosis and another study reported no significant association between visfatin and liver histology (8).

Many factors could result in this controversy, for example visfatin expression and function could be regulated by hormones (19), including sex hormones. Studies indicate that testosterone down-regulates visfatin expression by more than 2 folds than that of progesterone in preadipocytes (19), and estrogen increases visfatin expression in adipocytes (20).

\section{Objectives}

The current study aimed at exploring whether the association between serum visfatin and markers of hepatic injury is the same for both genders in patients with NAFLD.

\section{Methods}

\subsection{Design and Sample}

In this cross-sectional study, 62 patients with NAFLD, who referred to the liver disease clinic of Firoozgar hospital in Tehran, Iran, were recruited, consecutively. A related cross-sectional formula was used to calculate the sample size with a power of $80 \%$. The inclusion criteria were age of 18 years old or more with a diagnosis of steatosis based on ultrasonographic findings and controlled attenuation parameter (CAP) on fibroscan (21), and a stable body weight $( \pm 2 \%)$ and physical activity for at least 3 months before the study.

The exclusion criteria were a liver stiffness measurement (LSM) above 10 in the fibroscan (LSM is a marker of liver fibrosis, and advanced liver fibrosis may effect markers of hepatic fat infiltration and inflammation) (22), having diabetes (fasting blood sugar $\geq 126 \mathrm{mg} / \mathrm{dL}$ or use of blood glucose lowering drugs), drug abuse, exposure to chemical pollutants, use of steatogenic or hepatotoxic drugs (perhexiline maleate, amiodarone, calcium channel blockers, chloroquine, tamoxifen, methotrexate, synthetic estrogens, corticosteroids), use of drugs that effect weight (antipsychotics, antidepressants or hormone therapy), use of lipid lowering drugs, antioxidants and polyunsaturated fatty acid supplements in the 6 months prior to the study, endocrine disease, which effects weight (such as Cushing's syndrome, hyperprolactinemia, thyroid disorders, and congenital adrenal hyperplasia), kidney or heart disease, other acute or chronic liver diseases such as viral hepatitis or cirrhosis or a history of alcohol intake $(>20$ g/day).

This study was approved by the ethics committee of the medical university of Iran and was carried out in accordance with the Helsinki declaration (1975). All participants gave their written informed consent.

\subsection{Diagnosis of Fatty Liver in Sonography}

A fatty liver was diagnosed using sonography, which indicated an increase in hepatic echogenicity using renal echogenicity as a reference, enlargement of the liver and a lack of differentiation of the periportal and bile duct wall reinforcement because of advanced hyperechogenicity of the parenchyma (23).

\subsection{FibroScan}

FibroScan (Echosens; France) is an ultrasound-based vibration-controlled transient elastography device used to assess liver stiffness ( $\mathrm{kPa}$ correlated to fibrosis) as a noninvasive method. Ten measurements of stiffness ( $\mathrm{kPa}$ ) were performed by pressing a probe between the ribs. The median of the 10 measurements was compared with the designated values from the fibroscan scoring card. It quantifies steatosis at the same time using the controlled attenuation parameter (CAP), a measurement of ultrasound attenuation correlated to the decrease in amplitude of ultrasound waves as they spread through the liver. Fat effects ultrasound broadcasts, therefore, an increase in steatosis will result in a higher CAP value. The final CAP value was the median of individual measurements and ranged from 100 to 400 decibels per meter $(\mathrm{dB} / \mathrm{m})(22)$.

\subsection{Medical History, Dietary and Alcohol Intake}

Each participant was given a medical history questionnaire to complete. The habitual dietary intake of the participants was assessed using the semi-quantitative food frequency questionnaire consisting of 168 items that has been validated on a sample of a healthy population (24). Physical activity level was assessed using the long form of the international physical activity questionnaire (IPAQ) (25). Alcohol intake was estimated by recording the type of alcohol consumed, its volume and the frequency of consumption. A fatty liver was considered non-alcoholic if the patient consumed less than $20 \mathrm{~g}$ of alcohol per day. 


\subsection{Anthropometric Measurements}

Weight, height, waist, and hip circumferences were measured according to standard protocols (26). Body mass index (BMI) was calculated as body weight $(\mathrm{kg})$ divided by the square of height $(\mathrm{m})$ as $\mathrm{kg} / \mathrm{m}^{2}$.

\subsection{Biochemical Measurements}

A 12-hour fasting venous blood sample was taken from each participant to measure biochemical parameters. Serum aspartate aminotransferase (AST), Alanine aminotransferase (ALT), triglyceride (TG), total cholesterol, low density lipoprotein (LDL)-cholesterol, high density lipoprotein (HDL)-cholesterol and fasting blood glucose (FBS) were determined by auto analyzer alpha classic (Tehran, Iran) and Pars Azmoon reagent kits (Tehran, Iran). Insulin resistance was assessed using the homeostasis model assessment (HOMA) index as follows:

HOMA index $=[$ serum glucose $(\mathrm{mg} / \mathrm{dL}) \times$ serum insulin $(\mathrm{mU} / \mathrm{L})] / 405$.

Serum insulin (Diaplus; Canada), visfatin (BioVendor; Czech Republic), Caspase-cleaved cytokeratin 18 (cCK18, marker of hepatic apoptosis) (M30 kit, PEVIVA, Sweden) and total soluble Cytokeratin 18 (CK18, marker of hepatic apoptosis and necrosis) (M65 kit, PEVIVA, Sweden) (27) were measured by the enzyme linked immunosorbent assay (ELISA) method. Hepatitis B surface antigens (HbsAg), hepatitis B surface antibodies (HbsAb), hepatitis B core antibodies (HBcAb), hepatitis C virus antibodies (HCVAb), and antinuclear antibodies (ANA) were evaluated using thirdgeneration ELISA kits (Acon; USA).

\subsection{Statistical Analysis}

The Shapiro-Wilks test was used to check the normality of the continuous variables and arithmetic transformations were performed if necessary. Two independent sample t tests and chi-square test were used to compare continuous and categorical variables between genders, respectively.

Univariate linear regression was used to evaluate the relationship between serum visfatin as an independent variable and markers of hepatic injury (serum AST, ALT, CK18, cCK18, CAP, and LSM) as dependent variables in each gender, separately. Variables with $\mathrm{P}<0.2$ in univariate linear regression, were entered in the multiple-linear regression. In multiple-linear regression (backward method), all these relationships were adjusted for different factors (including dietary intake of energy and macronutrients, BMI, waist to hip ratio, HOMA index, age, blood lipid profile, and physical activity level), which had $\mathrm{P}<0.2$ in univariate linear regression. The $\mathrm{P}<0.05$ in multiple-linear regression was considered statistically significant. The SPSS software version 23 was used to analyze the data.

\section{Results}

The baseline characteristics of the participants are shown in Table 1 . This study included 62 patients with NAFLD, of which 32 were male and 30 were female. The participants were between 18 and 67 years of age. Females were significantly older ( $47.83 \pm 81.10$ vs $39.84 \pm 12.10, \mathrm{P}$ $=0.008)$, had higher BMI (32.31 \pm 4.56 vs $29.42 \pm 4.89, \mathrm{P}$ $=0.02)$, serum HDL level ( $50.31 \pm 11.05$ vs $43.03 \pm 7.41, \mathrm{P}=$ $0.004), \mathrm{CAP}(321.93 \pm 36.19$ vs $286.37 \pm 54.85, \mathrm{P}=0.004)$, and dietary fat intake (39.38 \pm 6.96 vs $35.2 \pm 6.13, \mathrm{P}=0.024)$, yet lower waist to hip $(\mathrm{W} / \mathrm{H})$ ratio $(0.87 \pm 0.05$ vs $0.9 \pm 0.06, \mathrm{P}$ $=0.022)$ and serum ALT level (36.44 \pm 24.87 vs $53.54 \pm 33.83$, $\mathrm{P}=0.03$ ) (Table 1$)$.

Serum visfatin, dietary energy, protein and carbohydrate intake, physical activity level, serum total cholesterol, LDL, triglyceride, FBS, insulin, and HOMA index were not significantly different between males and females.

4.1. Univariate and Multiple Linear Regression of Serum Visfatin with Biomarkers of Hepatic Injury and Fibroscan in Males with NAFLD

In univariate linear regression, serum visfatin had a significant positive association with serum AST $(B=0.44$, $\mathrm{P}=0.02)$, ALT $(\mathrm{B}=0.40, \mathrm{P}=0.03)$, CK18 $(\mathrm{B}=0.43, \mathrm{P}=0.02)$ and cCK18 $(\mathrm{B}=0.41, \mathrm{P}=0.03)$, yet, it had no significant associations with CAP or LSM.

Body mass index $(\mathrm{B}=0.40, \mathrm{P}=0.02)$, HOMA index $(\mathrm{B}=$ $0.74, \mathrm{P}<0.001)$ and serum triglyceride $(\mathrm{B}=0.73, \mathrm{P}<0.001)$ had a significant positive association with LSM (Table 2 ).

In multiple linear regression (after adjustment for confounding factors) serum visfatin still had its significant positive associations with serum AST $(\mathrm{B}=0.47$ and $\mathrm{P}=$ 0.009), ALT ( $\mathrm{B}=0.40$ and $\mathrm{P}=0.035), \mathrm{CK} 18(\mathrm{~B}=0.50$ and $\mathrm{P}$ $=0.008)$, and $\mathrm{cCK} 18(\mathrm{~B}=0.47$ and $\mathrm{P}=0.012)$.

Serum triglyceride also had a significant positive association with serum AST $(\mathrm{B}=0.35$ and $\mathrm{P}=0.047)$ and LSM (B $=0.40$ and $\mathrm{P}=0.01)$, HOMA index had a significant positive association with CAP $(\mathrm{B}=0.49$ and $\mathrm{P}=0.04)$ and $\operatorname{LSM}(\mathrm{B}=$ $0.49, \mathrm{P}=0.002)$, and waist to hip ratio had a significant positive association only with $\mathrm{CAP}(\mathrm{B}=0.46$ and $\mathrm{P}=0.02$ ) (Table 3).

4.2. Univariate and Multiple Linear Regression of Serum Visfatin with Biomarkers of Hepatic Injury and Fibroscan in Females with NAFLD

In univariate linear regression, serum visfatin had no significant associations with markers of hepatic injury (serum AST, ALT, CK18, cCK18, LSM, and CAP).

Body Mass Index had a significant positive association with serum ALT $(\mathrm{B}=0.41$ and $\mathrm{P}=0.03), \mathrm{CK} 18(\mathrm{~B}=0.46$ and $\mathrm{P}$ $=0.01)$, and $\operatorname{LSM}(B=0.43$ and $P=0.02)$. Waist to hip ratio 
Table 1. Baseline Characteristics of the Participants ${ }^{\mathrm{a}, \mathrm{b}}$

\begin{tabular}{|c|c|c|c|}
\hline Variables & Males, $\mathbf{n}=\mathbf{3 2}$ & Females, $\mathbf{n}=\mathbf{3 0}$ & P Value \\
\hline Age, year & $39.84 \pm 12.10$ & $47.83 \pm 10.62$ & $0.008^{\mathrm{b}}$ \\
\hline $\operatorname{BMI}\left(\mathrm{kg} / \mathrm{m}^{2}\right)$ & $29.42 \pm 4.89$ & $32.31 \pm 4.56$ & $0.02^{\mathrm{C}}$ \\
\hline $\mathbf{W} / \mathbf{H}$ ratio & $0.9 \pm 0.06$ & $0.87 \pm 0.05$ & $0.022^{c}$ \\
\hline FBS $(\mathrm{mg} / \mathrm{dL})$ & $105.37 \pm 22.37$ & $112.86 \pm 25.94$ & 0.23 \\
\hline Serum insulin (micIU/mL) & $12.77 \pm 9.47$ & $11.95 \pm 5.22$ & 0.70 \\
\hline HOMA index & $3.44 \pm 2.76$ & $3.31 \pm 1.62$ & 0.84 \\
\hline Serum total cholesterol $(\mathrm{mg} / \mathrm{dL})$ & $186.58 \pm 41.31$ & $196.91 \pm 37.92$ & 0.31 \\
\hline Serum LDL-cholesterol (mg/dL) & $115.90 \pm 41.20$ & $112.20 \pm 34.13$ & 0.71 \\
\hline Serum HDL-cholesterol (mg/dL) & $43.03 \pm 7.41$ & $50.31 \pm 11.05$ & $0.004^{\mathrm{b}}$ \\
\hline Serum triglyceride (mg/dL) & $137.35 \pm 74.13$ & $173.06 \pm 94.11$ & 0.11 \\
\hline Serum visfatin (ng/mL) & $2.44 \pm 1.07$ & $2.45 \pm 1.17$ & 0.98 \\
\hline $\operatorname{Serum} \operatorname{AST}(\mathbf{U} / \mathbf{L})$ & $43.32 \pm 19.38$ & $37.89 \pm 21.66$ & 0.31 \\
\hline $\operatorname{Serum} \operatorname{ALT}(\mathbf{U} / \mathbf{L})$ & $53.54 \pm 33.83$ & $36.44 \pm 24.87$ & $0.03^{c}$ \\
\hline Serum CK18 (U/L) & $505.97 \pm 345.60$ & $485.91 \pm 299.43$ & 0.81 \\
\hline Serum cCK18(U/L) & $227.53 \pm 235.13$ & $182.17 \pm 156.72$ & 0.39 \\
\hline $\operatorname{CAP}(\mathbf{d b} / \mathbf{m})$ & $286.37 \pm 54.85$ & $321.93 \pm 36.19$ & $0.004^{\mathrm{b}}$ \\
\hline LSM (kpa) & $7.05 \pm 3.52$ & $7.73 \pm 2.96$ & 0.41 \\
\hline Daily energy intake (kcal/d) & $2367.19 \pm 521.60$ & $2311.37 \pm 434.01$ & 0.68 \\
\hline Daily carbohydrate intake (\%) & $53.16 \pm 5.02$ & $50.31 \pm 6.05$ & 0.065 \\
\hline Daily protein intake (\%) & $13.51 \pm 2.04$ & $12.45 \pm 2.16$ & 0.07 \\
\hline Daily fat intake (\%) & $35.2 \pm 6.13$ & $39.38 \pm 6.96$ & $0.024^{c}$ \\
\hline Physical activity (METs-min/w) & $4419.54 \pm 7018.28$ & $1723.97 \pm 2841.17$ & 0.067 \\
\hline $\begin{array}{l}\text { Abbreviations: ALT, alanine aminotr } \\
\text { cytokeratin-18, CK } 18 \text {, Cytokeratin } 18 \text {, } \\
\text { task, W/H ratio: waist to hip ratio. } \\
\text { a Data are presented as Mean } \pm \text { SD. } \\
{ }^{b} \mathrm{P}<0.01 \text {. } \\
{ }^{\mathrm{C}} \mathrm{P}<0.05 \text {. }\end{array}$ & $\begin{array}{l}\text { MI, body Mass Index } \\
\text { model assessment, }\end{array}$ & $\begin{array}{l}\text { tenuation paramet } \\
\text { measurement, MET }\end{array}$ & $\begin{array}{l}\text { ase-cleave } \\
\text { uivalent }\end{array}$ \\
\hline
\end{tabular}

also had a significant positive association with serum AST ( $\mathrm{B}=0.37$ and $\mathrm{P}=0.048)$ and $\mathrm{ALT}(\mathrm{B}=0.41$ and $\mathrm{P}=0.03)$ (Table 4).

In multiple linear regression (after adjustment for confounding factors) serum visfatin only had a significant positive association with $\mathrm{CK} 18(\mathrm{~B}=0.37$ and $\mathrm{P}=0.045)$. Body mass index had a significant positive association with serum CK18 $(B=0.44, P=0.02)$, CCK18 $(B=0.42, P=0.02)$, CAP $(\mathrm{B}=0.39, \mathrm{P}=0.049)$, and LSM $(\mathrm{B}=0.40, \mathrm{P}=0.03)$. Waist to hip ratio had a significant positive association with serum AST $(B=0.37, P=0.04)$, ALT $(B=0.50, P=0.02)$, CK18 $(B=0.41, P=0.03), C C K 18(B=0.37, P=0.04)$, and CAP $(B=0.39, P=0.04)$. Serum triglyceride had a significant positive association only with serum $\mathrm{CCK} 18$ ( $\mathrm{B}=0.36$ and $\mathrm{P}$ $=0.043)$, and age had this significant positive association only with $\mathrm{CAP}(\mathrm{B}=0.46$ and $\mathrm{P}=0.02)$ (Table 5$)$.

\section{Discussion}

According to the findings of this study, the association of serum visfatin level with hepatic injury differed between males and females. In males, serum visfatin had a significant positive association with markers of hepatic inflammation, apoptosis, and total cell death, while in females it only had a weak association with the marker of total cell death. In females, waist to hip ratio and BMI were more associated with markers of hepatic inflammation, apoptosis, and total cell death.

According to previous studies, hepatic and adipose tissue were amongst the 2 main sources of visfatin (28). Females had a higher body fat content compared to males, thus adipose tissue in females could have had a greater effect on serum visfatin level compared to males. In fact it 
Table 2. Univariate Linear Regression of Hepatic Injury Biomarkers and Fibroscan Report with Serum Visfatin Level in Males with Nonalcoholic Fatty Liver Disease

\begin{tabular}{|c|c|c|c|c|c|c|c|c|c|c|c|c|}
\hline & \multicolumn{2}{|c|}{ Serum AST } & \multicolumn{2}{|c|}{ Serum ALT } & \multicolumn{2}{|c|}{ Serum CK18 } & \multicolumn{2}{|c|}{ Serum cCK18 } & \multicolumn{2}{|c|}{ CAP } & \multicolumn{2}{|c|}{ ISM } \\
\hline & в & P.V & в & P.V & в & P.V & в & P.V & в & P.V & в & P.V \\
\hline Serum visfatin & 0.44 & $0.02^{\mathrm{a}}$ & 0.40 & $0.03^{\mathrm{a}}$ & 0.43 & $0.02^{\mathrm{a}}$ & 0.41 & $0.03^{\mathrm{a}}$ & 0.28 & $0.14^{\mathrm{a}}$ & -0.13 & 0.51 \\
\hline Age & -0.05 & 0.77 & -0.26 & $0.15^{\mathrm{a}}$ & -0.16 & 0.38 & -0.13 & 0.47 & 0.15 & 0.41 & -0.11 & 0.56 \\
\hline BMI & 0.21 & 0.26 & 0.21 & 0.25 & 0.072 & 0.70 & 0.21 & 0.25 & 0.22 & 0.22 & 0.40 & $0.02^{\mathrm{a}}$ \\
\hline W/H ratio & 0.22 & 0.22 & 0.20 & 0.28 & 0.19 & 0.31 & 0.29 & $0.11^{\mathrm{a}}$ & 0.30 & $0.10^{\mathrm{a}}$ & 0.33 & $0.06^{\mathrm{a}}$ \\
\hline НОМА & 0.19 & 0.31 & 0.05 & 0.78 & -0.03 & 0.88 & 0.16 & 0.41 & 0.35 & $0.06^{\mathrm{a}}$ & 0.74 & $0.000^{\mathrm{a}}$ \\
\hline Serum total cholesterol & 0.17 & 0.36 & 0.13 & 0.47 & -0.18 & 0.34 & 0.03 & 0.88 & -0.01 & 0.94 & -0.16 & 0.38 \\
\hline Serum LDL-cholesterol & 0.07 & 0.72 & 0.06 & 0.74 & 0.18 & 0.33 & -0.02 & 0.92 & -0.14 & 0.46 & -0.38 & 0.034 \\
\hline Serum triglyceride & 0.32 & $0.08^{\mathrm{a}}$ & 0.19 & 0.31 & 0.10 & 0.59 & 0.21 & 0.25 & 0.21 & 0.24 & 0.73 & $0.000^{\mathrm{a}}$ \\
\hline Daily energy intake & 0.01 & 0.98 & -0.16 & 0.40 & 0.01 & 0.94 & -0.03 & 0.86 & 0.053 & 0.78 & -0.09 & 0.61 \\
\hline Daily carbohydrate intake & 0.04 & 0.83 & 0.07 & 0.71 & 0.24 & 0.20 & 0.11 & 0.57 & -0.07 & 0.68 & -0.22 & 0.24 \\
\hline Daily protein intake & -0.06 & 0.76 & 0.14 & 0.47 & 0.12 & 0.53 & 0.06 & 0.76 & -0.13 & 0.47 & -0.13 & 0.47 \\
\hline Daily fat intake & -0.02 & 0.92 & -0.15 & 0.44 & -0.27 & $0.15^{\mathrm{a}}$ & 0.12 & 0.51 & 0.12 & 0.53 & 0.26 & $0.15^{\mathrm{a}}$ \\
\hline Physical activity & -0.06 & 0.74 & -0.12 & 0.54 & 0.26 & $0.17^{\mathrm{a}}$ & 0.20 & 0.28 & -0.03 & 0.86 & -0.10 & 0.58 \\
\hline
\end{tabular}

Abbreviations: ALT, alanine aminotransferase; AST, aspartate aminotransferase; BMI, body mass index; CAP, controlled attenuation parameter; cCK18, caspase-cleaved cytokeratin-18; CK 18, cytokeratin 18; HOMA, homeostasis model assessment; LSM, liver stiffness measurement; NAFLD, nonalcoholic fatty liver disease; $\mathrm{W} / \mathrm{H}$ ratio, waist to hip ratio.

Table 3. Multiple Linear Regression of Hepatic Injury Biomarkers and Fibroscan Report with Serum Visfatin Level in Males with Nonalcoholic Fatty Liver Disease

\begin{tabular}{|c|c|c|c|c|c|c|c|c|c|c|c|c|}
\hline & \multicolumn{2}{|c|}{ Serum AST } & \multicolumn{2}{|c|}{ Serum ALT } & \multicolumn{2}{|c|}{ Serum CK18 } & \multicolumn{2}{|c|}{ Serum cCK 18} & \multicolumn{2}{|c|}{ CAP } & \multicolumn{2}{|c|}{ ISM } \\
\hline & B & P.V & В & P.V & B & P.V & B & P.V & В & P.V & B & P.V \\
\hline Serum visfatin & 0.47 & $0.009^{\mathrm{a}}$ & 0.40 & $0.035^{\mathrm{b}}$ & 0.50 & $0.008^{a}$ & 0.47 & $0.012^{\mathrm{b}}$ & - & - & - & - \\
\hline W/H ratio & - & - & - & - & - & - & - & . & 0.46 & $0.02^{\mathrm{b}}$ & - & - \\
\hline НОМА & - & - & - & - & - & - & - & - & 0.49 & $0.04^{\mathrm{b}}$ & 0.49 & $0.002^{\mathrm{a}}$ \\
\hline Serum triglyceride & 0.35 & $0.047^{\mathrm{b}}$ & - & - & - & - & - & - & - & - & 0.40 & $0.01^{\mathrm{b}}$ \\
\hline $\begin{array}{l}\text { Abbreviations: ALT, al } \\
\text { stiffness measuremen } \\
\mathrm{a}_{\mathrm{P}}<0.01 \text {. } \\
\mathrm{b}_{\mathrm{P}}<0.05 \text {. }\end{array}$ & ; & $\begin{array}{l}\text { e amino } \\
\text { se; } \mathrm{W} / \mathrm{H}\end{array}$ & $\begin{array}{l}\mathrm{se} \text {; CA } \\
\text { th to hi }\end{array}$ & & & & cytok & & & tomeost & del asses & LSM, liver \\
\hline
\end{tabular}

Table 4. Univariate Linear Regression of Hepatic Injury Biomarkers and Fibroscan Report with Serum Visfatin Level in Females with Nonalcoholic Fatty Liver Disease

\begin{tabular}{|c|c|c|c|c|c|c|c|c|c|c|c|c|}
\hline & \multicolumn{2}{|c|}{ Serum AST } & \multicolumn{2}{|c|}{ Serum ALT } & \multicolumn{2}{|c|}{ Serum CK18 } & \multicolumn{2}{|c|}{ Serum cCK18 } & \multicolumn{2}{|c|}{ CAP } & \multicolumn{2}{|c|}{ ISM } \\
\hline & в & P.V & в & P.V & в & P.V & в & P.V & в & P.V & в & P.V \\
\hline Serum visfatin & 0.15 & 0.43 & 0.05 & 0.79 & 0.27 & $0.16^{\mathrm{a}}$ & 0.10 & 0.63 & -0.12 & 0.54 & -0.36 & $0.06^{\mathrm{a}}$ \\
\hline Age & -0.05 & 0.80 & -0.17 & 0.38 & -0.19 & 0.31 & -0.18 & 0.35 & 0.35 & $0.06^{\mathrm{a}}$ & 0.06 & 0.75 \\
\hline BMI & 0.32 & $0.09^{\mathrm{a}}$ & 0.41 & $0.03^{\mathrm{a}}$ & 0.46 & $0.01^{\mathrm{a}}$ & 0.26 & $0.18^{\mathrm{a}}$ & 0.27 & $0.15^{\mathrm{a}}$ & 0.43 & $0.02^{\mathrm{a}}$ \\
\hline W/H ratio & 0.37 & $0.048^{a}$ & 0.41 & $0.03^{\mathrm{a}}$ & 0.29 & $0.12^{\mathrm{a}}$ & 0.31 & $0.11^{\mathrm{a}}$ & 0.24 & 0.20 & -0.001 & 0.99 \\
\hline нОМА & -0.05 & 0.79 & 0.05 & 0.80 & 0.09 & 0.65 & 0.31 & $0.13^{\mathrm{a}}$ & -0.09 & 0.64 & 0.19 & 0.32 \\
\hline Serum total cholesterol & -0.03 & 0.86 & 0.09 & 0.66 & -0.01 & 0.95 & -0.10 & 0.60 & 0.30 & $0.10^{\mathrm{a}}$ & 0.03 & 0.88 \\
\hline Serum LDL-cholesterol & -0.10 & 0.61 & 0.04 & 0.84 & -0.07 & 0.72 & -0.21 & 0.29 & 0.13 & 0.49 & 0.12 & 0.53 \\
\hline Serum triglyceride & 0.22 & 0.24 & 0.18 & 0.36 & 0.29 & $0.14^{\mathrm{a}}$ & 0.38 & $0.05^{\mathrm{a}}$ & 0.27 & $0.15^{\mathrm{a}}$ & -0.17 & 0.37 \\
\hline Daily energy intake & 0.15 & 0.50 & 0.23 & 0.29 & -0.06 & 0.79 & -0.005 & 0.98 & 0.08 & 0.73 & -0.17 & 0.44 \\
\hline Daily carbohydrate intake & -0.06 & 0.78 & -0.28 & 0.21 & 0.14 & 0.52 & -0.05 & 0.82 & 0.18 & 0.41 & 0.07 & 0.74 \\
\hline Daily protein intake & -0.10 & 0.67 & -0.04 & 0.85 & -0.14 & 0.54 & -0.09 & 0.67 & -0.28 & $0.19^{\mathrm{a}}$ & -0.09 & 0.68 \\
\hline Daily fat intake & 0.13 & 0.58 & 0.29 & $0.19^{\mathrm{a}}$ & -0.06 & 0.80 & 0.10 & 0.64 & -0.05 & 0.82 & 0.006 & 0.98 \\
\hline Physical activity & 0.14 & 0.51 & 0.16 & 0.43 & 0.26 & 0.20 & 0.05 & 0.80 & 0.21 & 0.29 & 0.19 & 0.35 \\
\hline
\end{tabular}

Abbreviations: ALT, alanine aminotransferase; AST, aspartate aminotransferase; BMI, body mass index; CAP, controlled attenuation parameter; cCK18, caspase-cleaved cytokeratin-18; CK 18, cytokeratin 18; HOMA, homeostasis model assessment; LSM, liver stiffness measurement; NAFLD, nonalcoholic fatty liver disease; W/H ratio, waist to hip ratio.

${ }^{\mathrm{a}} \mathrm{P}<0.2$.

may be that serum visfatin level in females is more related to its adipose tissue level, yet in males serum visfatin level is more related to its hepatic level. This could be the reason for the strong association between serum visfatin level and 
Table 5. Multiple Linear Regression of Hepatic Injury Biomarkers and Fibroscan Report With Serum Visfatin Level in Females With Nonalcoholic Fatty Liver Disease

\begin{tabular}{|c|c|c|c|c|c|c|c|c|c|c|c|c|}
\hline & \multicolumn{2}{|c|}{ Serum AST } & \multicolumn{2}{|c|}{ Serum ALT } & \multicolumn{2}{|c|}{ Serum CK18 } & \multicolumn{2}{|c|}{ Serum cCK18 } & \multicolumn{2}{|c|}{ CAP } & \multicolumn{2}{|c|}{ ISM } \\
\hline & B & P.V & в & P.V & в & P.V & B & P.V & в & P.V & B & P.V \\
\hline Serum visfatin & - & - & - & - & 0.37 & $0.045^{\mathrm{a}}$ & - & - & - & - & - & - \\
\hline Age & - & - & . & - & & - & - & - & 0.46 & $0.02^{\mathrm{a}}$ & $\cdot$ & - \\
\hline BMI & - & - & - & - & 0.44 & $0.02^{\mathrm{a}}$ & 0.42 & $0.02^{\mathrm{a}}$ & 0.39 & $0.049^{\mathrm{a}}$ & 0.40 & $0.03^{\mathrm{a}}$ \\
\hline W/H ratio & 0.37 & $0.04^{\mathrm{a}}$ & 0.50 & $0.02^{\mathrm{a}}$ & 0.41 & $0.03^{\mathrm{a}}$ & 0.37 & $0.04^{\mathrm{a}}$ & 0.39 & $0.04^{\mathrm{a}}$ & - & - \\
\hline Serum triglyceride & . & . & . & . & . & . & 0.36 & $0.043^{\mathrm{a}}$ & . & - & - & - \\
\hline
\end{tabular}

markers of hepatic injury in males but not in females.

On the other hand, studies have shown that testosterone down regulates visfatin expression in preadipocytes and estrogen induces visfatin expression in adipocytes (19). These findings also support the greater impact of adipose tissue on serum visfatin level in females than males and this is in accordance with our findings.

Previous studies also indicate that visfatin has an important enzymatic role in De Novo Lipogenesis (DNL) (11, 27 ), which is known to be increased in $\operatorname{NAFLD}(29,30)$, yet hepatic and adipose tissue DNL have opposing effects on the prognosis of NAFLD. Hepatic DNL is positively correlated yet adipose tissue DNL is negatively correlated with fatty liver $(31,32)$. Based on this knowledge, it is logical that serum visfatin level and markers of hepatic injury have no significant associations, where serum visfatin level is more associated with its level in adipose tissue. This is exactly what was observed in the current study. No significant associations were found between serum visfatin level and markers of hepatic injury in females whose higher body fat content could have a greater effect on serum visfatin level.

According to these findings, serum visfatin level may have different prognosis for each gender in NAFLD, and the contrary findings for the association between serum visfatin and pathologic findings of NAFLD (14) could be partly due to different gender distribution in various studies.

Another finding of this study was that, after visfatin, HOMA index had the most significant positive association with markers of hepatic injury (hepatic fat infiltration and fibrosis). However, in females, HOMA index was not significantly associated with markers of hepatic injury. Instead, BMI and waist to hip ratio had the most significant positive associations with markers of hepatic injury (hepatic inflammation, apoptosis, necrosis, fat infiltration, and fibrosis) in females.

This may indicate that males could be more susceptible to peripheral insulin resistance compared to females. Different adiposity distribution between males and females may explain this finding. According to previous stud- ies, fat accumulation in females is more in the glutealfemoral region, while in males it is more in visceral (abdominal) depot, and there are distinct differences in fatty acid metabolism between these 2 regions (33). Lipolytic activity and response to insulin, adrenergic and angiotensin stimulation, and sex hormones are completely different between visceral and peripheral adipocytes. Visceral fat is a major source of circulating free fatty acids and cytokines, which are directly transported via the portal vein to the liver inducing hepatic insulin resistance and an atherogenic lipid profile (34). Therefore, increased peripheral insulin resistance results in more hepatic injury in males, who have higher visceral adipose tissue compared to females.

To the best of our knowledge, this is the first study directing gender influence on the association between serum visfatin and hepatic injuries in NAFLD. The associations were adjusted for other variables that could influence hepatic injuries including age, BMI, waist to hip ratio, HOMA index, blood lipid profile, dietary energy, macronutrient intake, and physical activity level, so that the independence of the associations could be confirmed.

This study also had some limitations. More detailed studies with larger sample sizes are needed to completely understand the association between serum visfatin level and hepatic injuries in patients with NAFLD and the influence of gender on this association. For example, direct measurement of visfatin level in hepatic and adipose tissue of each gender separately, and investigating biopsyproven pathologic findings, may further clarify these associations in NAFLD. Although all the associations in this study were adjusted for confounding variables (including age, BMI and...) that could influence hepatic injuries, yet it is suggested to perform further studies on males and females to more carefully adjust for these confounders.

\subsection{Conclusion}

Serum visfatin level may have different prognosis for each gender in NAFLD. While its increased serum level 
could be an indicator for more hepatic injury in males, this is not the case in females. Body Mass Index and waist to hip ratio were stronger predictors for hepatic injury in females. Based on these results, the contrary findings for the association between serum visfatin and pathologic findings of NAFLD (14) could be partly due to different gender distribution in various studies.

\section{Acknowledgments}

The authors express their gratitude to Dr Hossein Keyvani and his colleagues (Keivan virology lab, Tehran, Iran) for their valuable assistance in this research.

\section{Footnotes}

Authors' Contribution: Concept and design: Bahareh Amirkalali and Farhad Zamani; acquisition of data: Bahareh Amirkalali; analysis and interpretation of data: Ali Gholami; drafting of the manuscript: Bahareh Amirkalali; critical revision of the manuscript for important intellectual content: Farhad Zamani, Farzad Shidfar, and Masoud Reza Sohrabi; statistical analysis: Ali Gholami; administrative, technical, and material support: Masoud Reza Sohrabi, and Payam Hosseinzadeh; study supervision: Farhad Zamani and Farzad Shidfar

Financial Disclosure: The authors of this manuscript declare that they had no financial interests related to the material in the manuscript.

Funding/Support: This study was supported by Iran University of Medical Sciences.

Implication for Health Policy Mak-
ers/Practice/Research/Medical Education: The results of this study could help better interpretation of serum visfatin level in the progress of Nonalcoholic Fatty Liver Disease and better classify the risk factors for the disease progression in each gender, separately.

Role of the Sponsor: Iran University of Medical Sciences scientifically and ethically assessed the proposal of this study and financially supported this research.

\section{References}

1. Younossi ZM, Stepanova M, Afendy M, Fang Y, Younossi Y, Mir H, et al. Changes in the prevalence of the most common causes of chronic liver diseases in the United States from 1988 to 2008. Clin Gastroenterol Hepatol. 2011;9(6):524-30. doi: 10.1016/j.cgh.2011.03.020. [PubMed: 21440669]

2. Motamed N, Sohrabi M, Ajdarkosh H, Hemmasi G, Maadi M, Sayeedian FS, et al. Fatty liver index vs waist circumference for predicting nonalcoholic fatty liver disease. World J Gastroenterol. 2016;22(10):3023-30. doi: 10.3748/wjg.v22.i10.3023. [PubMed: 26973398].
3. Fan JG. Epidemiology of alcoholic and nonalcoholic fatty liver disease in China. J Gastroenterol Hepatol. 2013;28 Suppl 1:11-7. doi: 10.1111/jgh.12036. [PubMed: 23855290].

4. Liu Q, Bengmark S, Qu S. The role of hepatic fat accumulation in pathogenesis of non-alcoholic fatty liver disease (NAFLD). Lipids Health Dis. 2010;9:42. doi: 10.1186/1476-511X-9-42. [PubMed: 20426802].

5. Malik SM, deVera ME, Fontes P, Shaikh O, Ahmad J. Outcome after liver transplantation for NASH cirrhosis. Am JTransplant. 2009;9(4):782-93. doi: 10.1111/j.1600-6143.2009.02590.x. [PubMed: 19344467].

6. Turati F, Talamini R, Pelucchi C, Polesel J, Franceschi S, Crispo A, et al. Metabolic syndrome and hepatocellular carcinoma risk. Br J Cancer. 2013;108(1):222-8. doi:10.1038/bjc.2012.492. [PubMed: 23169288].

7. Mirza MS. Obesity, Visceral Fat, and NAFLD: Querying the Role of Adipokines in the Progression of Nonalcoholic Fatty Liver Disease. ISRN Gastroenterol. 2011;2011:592404. doi: 10.5402/2011/592404. [PubMed: 21991518]

8. Genc H, Dogru T, Kara M, Tapan S, Ercin CN, Acikel C, et al. Association of plasma visfatin with hepatic and systemic inflammation in nonalcoholic fatty liver disease. Ann Hepatol. 2013;12(4):548-55. [PubMed: 23813132].

9. Samal B, Sun Y, Stearns G, Xie C, Suggs S, McNiece I. Cloning and characterization of the cDNA encoding a novel human pre-B-cell colonyenhancing factor. Mol Cell Biol. 1994;14(2):1431-7. [PubMed: 8289818].

10. Yang H, Lavu S, Sinclair DA. Nampt/PBEF/Visfatin: a regulator of mammalian health and longevity? Exp Gerontol. 2006;41(8):718-26. doi: 10.1016/j.exger.2006.06.003. [PubMed:16842957].

11. Yang CC, Deng SJ, Hsu CC, Liu BH, Lin EC, Cheng WT, et al. Visfatin regulates genes related to lipid metabolism in porcine adipocytes. J Anim Sci. 2010;88(10):3233-41. doi: 10.2527/jas.2010-2799. [PubMed: 20562354].

12. Akbal E, Kocak E, Tas A, Yuksel E, Koklu S. Visfatin levels in nonalcoholic fatty liver disease. I Clin Lab Anal. 2012;26(2):115-9. doi: 10.1002/jcla.21491. [PubMed: 22467327].

13. Auguet T, Terra X, Porras JA, Orellana-Gavalda JM, Martinez S, Aguilar $\mathrm{C}$, et al. Plasma visfatin levels and gene expression in morbidly obese women with associated fatty liver disease. Clin Biochem. 2013;46(3):202-8. doi: 10.1016/j.clinbiochem.2012.11.006. [PubMed: 23174488].

14. Bekaert M, Verhelst X, Geerts A, Lapauw B, Calders P. Association of recently described adipokines with liver histology in biopsyproven non-alcoholic fatty liver disease: a systematic review. Obes Rev. 2016;17(1):68-80. doi: 10.1111/obr.12333. [PubMed: 26597657].

15. Aller R, de Luis DA, Izaola O, Sagrado MG, Conde R, Velasco MC, et al. Influence of visfatin on histopathological changes of non-alcoholic fatty liver disease. Dig Dis Sci. 2009;54(8):1772-7. doi: 10.1007/s10620008-0539-9. [PubMed: 19005759].

16. Dahl TB, Haukeland JW, Yndestad A, Ranheim T, Gladhaug IP, Damas $\mathrm{JK}$, et al. Intracellular nicotinamide phosphoribosyltransferase protects against hepatocyte apoptosis and is down-regulated in nonalcoholic fatty liver disease. JClin Endocrinol Metab. 2010;95(6):3039-47. doi: 10.1210/jc.2009-2148. [PubMed: 20392873].

17. Jarrar MH, Baranova A, Collantes R, Ranard B, Stepanova M, Bennett $\mathrm{C}$, et al. Adipokines and cytokines in non-alcoholic fatty liver disease. Aliment Pharmacol Ther. 2008;27(5):412-21. doi: 10.1111/j.13652036.2007.03586.x. [PubMed: 18081738].

18. Younossi ZM, Jarrar M, Nugent C, Randhawa M, Afendy M, Stepanova $\mathrm{M}$, et al. A novel diagnostic biomarker panel for obesity-related nonalcoholic steatohepatitis (NASH). Obes Surg. 2008;18(11):1430-7. doi: 10.1007/s11695-008-9506-y. [PubMed: 18500507].

19. MacLaren R, Cui W, Cianflone K. Visfatin expression is hormonally regulated by metabolic and sex hormones in 3T3-L1 pre-adipocytes and adipocytes. Diabetes Obes Metab. 2007;9(4):490-7. doi: 10.1111/j.14631326.2006.00625.x. [PubMed: 17587391].

20. Zhou J, Seidel ER. Estrogens induce visfatin expression in 3T3-L1 cells. Peptides. 2010;31(2):271-4. doi: 10.1016/j.peptides.2009.12.004. [PubMed: 20004694]. 
21. Sasso M, Tengher-Barna I, Ziol M, Miette V, Fournier C, Sandrin L, et al. Novel controlled attenuation parameter for noninvasive assessment of steatosis using Fibroscan $((\mathrm{R}))$ : validation in chronic hepatitis C. J Viral Hepat. 2012;19(4):244-53. doi: 10.1111/j.1365-2893.2011.01534.x. [PubMed: 22404722].

22. Sandrin L, Fourquet B, Hasquenoph JM, Yon S, Fournier C, Mal F, et al. Transient elastography: a new noninvasive method for assessment of hepatic fibrosis. Ultrasound Med Biol. 2003;29(12):1705-13. [PubMed: 14698338].

23. Sanyal AJ, American Gastroenterological A. AGA technical review on nonalcoholic fatty liver disease. Gastroenterology. 2002;123(5):170525. [PubMed: 12404245$]$

24. Esmaillzadeh A, Mirmiran P, Azizi F. Whole-grain intake and the prevalence of hypertriglyceridemic waist phenotype in Tehranian adults. Am J Clin Nutr. 2005;81(1):55-63. [PubMed:15640460].

25. Craig CL, Marshall AL, Sjostrom M, Bauman AE, Booth ML, Ainsworth $\mathrm{BE}$, et al. International physical activity questionnaire: 12-country reliability and validity. Med Sci Sports Exerc. 2003;35(8):1381-95. doi: 10.1249/01.MSS.0000078924.61453.FB. [PubMed:12900694].

26. McDowell MA, Statistics NCH. Anthropometric reference data for children and adults: Us population, 1999-2002: Us department of health and human services, centers for disease control and prevention. $\mathrm{Na}$ tional Center for Health Statistics; 2005.

27. Bowlby SC, Thomas MJ, D’Agostino RB, Kridel SJ. Nicotinamide phosphoribosyl transferase (Nampt) is required for de novo lipogenesis in tumor cells. PLoS One. 2012;7(6):40195. doi: 10.1371/jour- nal.pone.0040195. [PubMed: 22768255].

28. Ali Mohammad S, Nawas SS, Siddiqui IA, Sasikala M, Mukarjee RM, Rao N. Circulating visfatin and proinflammatory cytokine levels in nonalcoholic fatty liver disease. Int J Curr Res. 2014;6(8):8159-62.

29. Lee JJ, Lambert JE, Hovhannisyan Y, Ramos-Roman MA, Trombold JR, Wagner DA, et al. Palmitoleic acid is elevated in fatty liver disease and reflects hepatic lipogenesis. Am J Clin Nutr. 2015;101(1):34-43. doi: 10.3945/ajcn.114.092262. [PubMed: 25527748].

30. Donnelly KL, Smith CI, Schwarzenberg SJ, Jessurun J, Boldt MD, Parks EJ. Sources of fatty acids stored in liver and secreted via lipoproteins in patients with nonalcoholic fatty liver disease. J Clin Invest. 2005;115(5):1343-51. doi: 10.1172/JCI23621. [PubMed: 15864352].

31. Solinas G, Boren J, Dulloo AG. De novo lipogenesis in metabolic homeostasis: More friend than foe? Mol Metab. 2015;4(5):367-77. doi: 10.1016/j.molmet.2015.03.004. [PubMed: 25973385].

32. Minehira K, Vega N, Vidal H, Acheson K, Tappy L. Effect of carbohydrate overfeeding on whole body macronutrient metabolism and expression of lipogenic enzymes in adipose tissue of lean and overweight humans. Int J Obes Relat Metab Disord. 2004;28(10):1291-8. doi: 10.1038/sj.ijo.0802760. [PubMed: 15303106].

33. Blaak E. Gender differences in fat metabolism. Curr Opin Clin Nutr Metab Care. 2001;4(6):499-502. [PubMed: 11706283].

34. Regitz-Zagrosek V, Lehmkuhl E, Weickert MO. Gender differences in the metabolic syndrome and their role for cardiovascular disease. Clin Res Cardiol. 2006;95(3):136-47. doi: 10.1007/s00392-006-0351-5. [PubMed: 16598526]. 